\title{
The Effort of Economic Growth through Foreign Direct Investment in Libya
}

\author{
Alsnusy O. Alfadel ${ }^{1}$, Kertahadi M. Com ${ }^{2}$, Imam Saudi $^{3}$ \\ ${ }^{1,2.3}$ Faculty of administrative science, Brawijaya University, Indonesia
}

\begin{abstract}
Today, most countries strive to attract foreign direct investment (FDI) because of its acknowledged advantages as a tool of economic development. Africa and Libya in particular joined the rest of the world in seeking FDI as evidenced by the formation of the New Partnership for Africa's Development (NEPAD), which has the attraction of foreign investment to Africa as a major component. North Africa as a region now has to depend very much on FDI for so many reasons, the preference for FDI stems from its acknowledged advantages. Foreign direct investment (FDI) is an integral part of an open and effective international economic system and a major catalyst to development. Yet, the benefits of FDI do not accrue automatically and evenly across countries, sectors and local communities. National policies and the international investment architecture matter for attracting FDI to a larger number of developing countries and for reaping the full benefits of FDI for development. The challenges primarily address host countries, which need to establish a transparent, broad and effective enabling policy environment for investment and to build the human and institutional capacities to implement them. Hence, in this report, we description the effort on foreign direct investment in Libya and evaluate the effort on foreign direct investment in Libya and What are the challenges faces by Libya on foreign direct investment and propose possible solution through looking at various factors that hinders or support foreign direct investment.
\end{abstract}

Keywords: Libya, Foreign direct investment (FDI), economic growth, National policy.

\section{Introduction}

A viable for tool for economic, the openness to the world economy leads to industrialization, job creation, income growth, and development in the home country. Through exports, a country is able to experience a higher demand for its goods and services, increasing the output levels. Importing goods and services from foreign countries is said to enhance efficiency and productivity of domestic firms, leading to economic growth. Moreover, foreign direct investments (FDI) and international trade may influence the rate of economic growth such that conditional convergence occurs FDI improves the productivity of host countries and stimulates thus economic growth. As a consequence of technological spillovers, FDI increases the productivity not only on the firms which receive these investments, but potentially on all host-country firms and individuals. In either case, the impact of FDI inflow depends on the ability to absorb it in a nation, Abobaker Salem (2011).

However, to evaluate the effort on FDI in Libya and relationship between growth and exports, a comparison is made between FDI-led growth and export-led growth in selected North African countries Andrew W. Lo (2012). However there are just very such report available so there are greater need to address hi gap by providing comphresive report on effort of FDI in Libya This reported presented foreign direct investment (FDI) and effort for economic growth made in Libya, the degree of trade openness is measured by the share of the sum of exports plus imports to GDP these element are included in this report as a stimulant for economic growth Barlow D. (2006) . Economists consider that higher GDP growth rate will translate to a better quality of economic life and greater prosperity for the people Coker Margaret and Rappaport, Liz (2011). But that may be has not happened for many people. Instead in cities around the world the " 99 percent" have protested in the occupy movement against an unfair distribution income and wealth, and should be avoided accumulate wealth and resources by the top one percent Vadlamannati, K., (2009).

\section{Trend FDI growth in Libya}

Libyan economic vulnerabilities stepped up significantly from early 1997 through the period following the onset of the crisis in mid-1997, as market confidence increasingly diminished along with the rest of the region. Large portfolio outflows took place, and equity and property values declined substantially, the Libyan dinar (LYD) came under tremendous pressure.

As currency traders took speculative positions in the region Libyan dinar (LYD) market in anticipation of a large devaluation, the offshore Libyan dinar (LYD) interest rates increased markedly relative to domestic rates. This heightened upward pressure on domestic interest rates, intensified outflows of Libyan dinar (LYD) funds, and exacerbated banks' liquidity problems and overall financial distress. The Libyan corporate sector experienced significant loss of wealth as a result of sharp falls in the value of real estate and equities used as 
bank collateral. Corporate incomes and cash flows also declined, leaving some corporations unable to service their debt.

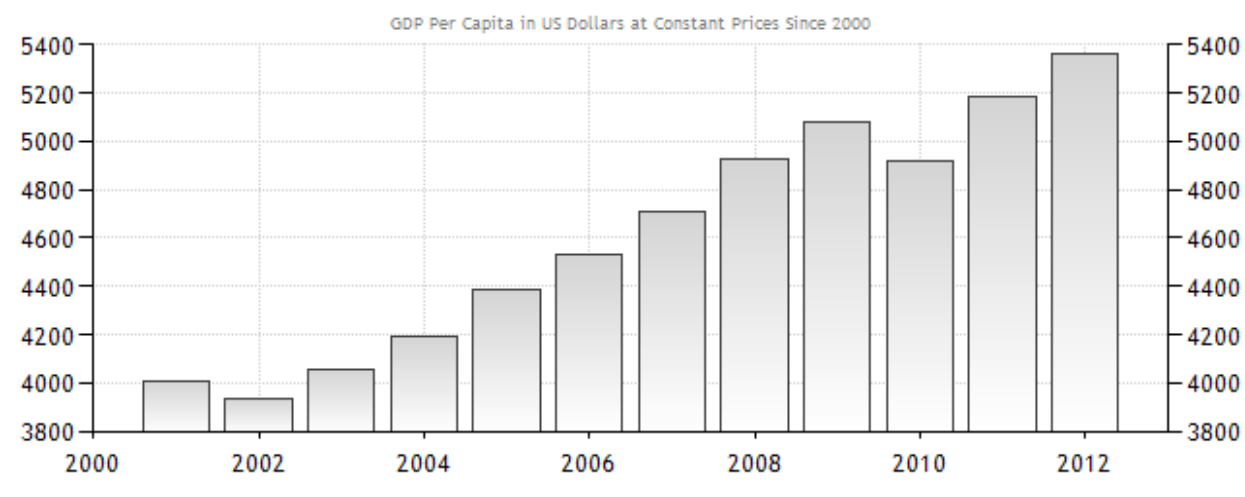

SOURCE: WWW.TRADINGECONOMICS.COM I WORLD BANK

Chart 1 Libyan GDP per Capita.

Source: International Monetary Fund - 2011 World Economic Outlook

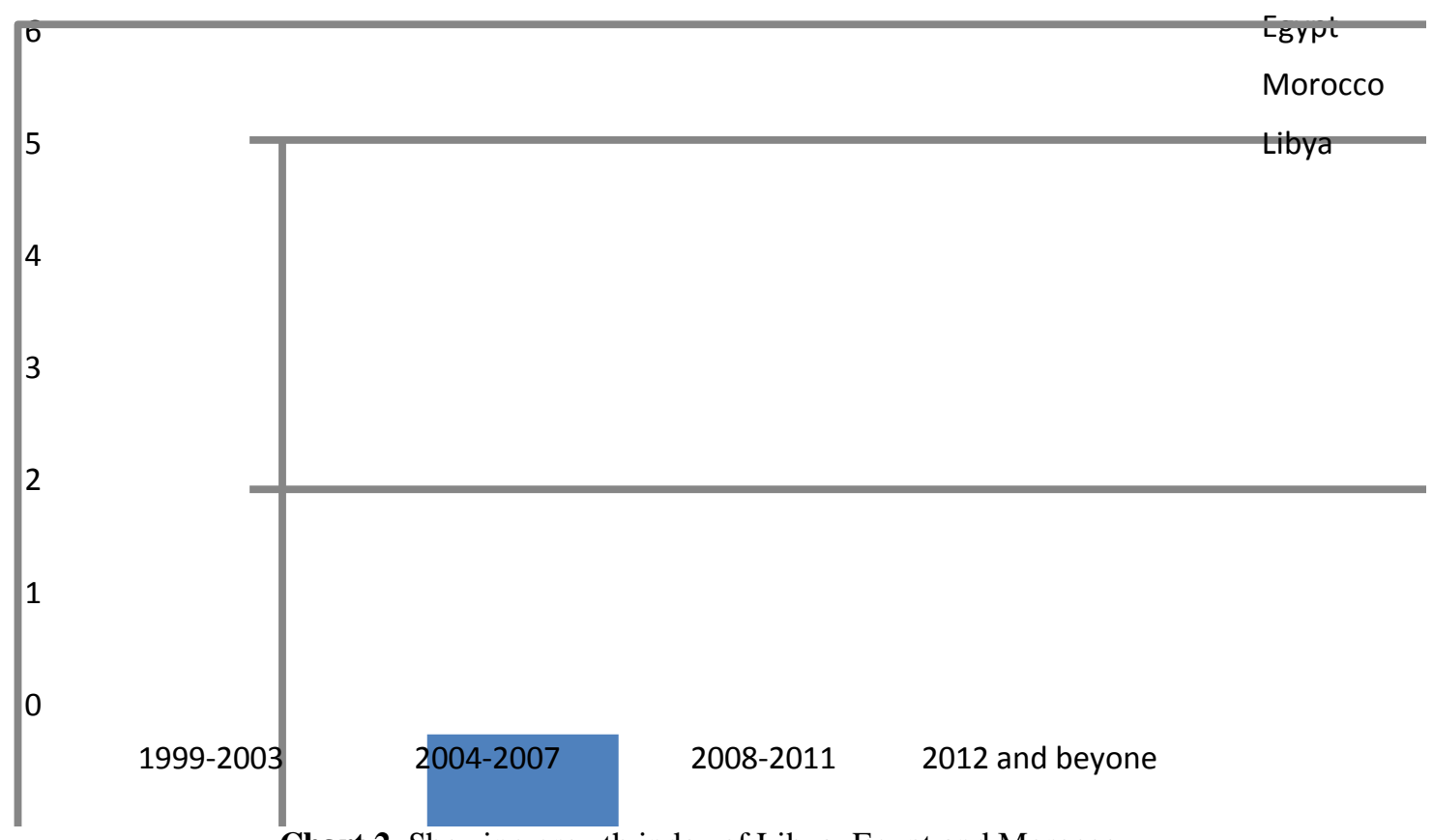

Chart 2. Showing growth index of Libya, Egypt and Morocco

Beneath these apparently sound economic fundamentals all was not well, draw attention to the fact that total factor productivity (TFP) growth had been declining prior to 1997, indicating the loss of efficiency in the economy. This was further exacerbated by the high wage increases that exceeded productivity gains. the high growth rates in the years preceding the crisis were achieved primarily by capital stock accumulation. During this period increases in output fell short of increases in capital. It is during this period that the country witnessed the inception of 'mega projects' involving considerable imported equipment Dhakal, I.P. (2002).

Economic growth in Libya was start developing and measured by GDP, however the second source of concern was the rapid growth in bank loans to the property sector the trend can observed in chart 1 and 2. Roughly between 1991 and 1996 there was a boom in property prices ranging annually from 10 to 17 percent. Property developers sought bank loans using stocks and property as collateral. This exposed the economy to two forms of risk, there were considered in the account. First, there were signs of excess supply in the property market Second, with the extremely high prices in the stock and property markets, banks were exposing themselves to risk in the event of a sudden fall in prices in these markets. The rapid growth in bank loans to the property sector was symptomatic of the preference structure of banks in respect to extending loans. Banks 
preferred to make loans where high rates of return appeared to be assured, rather than to extend them for longterm investments.

Banks more readily extended loans for consumption credit, real estate investments and share purchases rather than for manufacturing, agriculture or building and construction, or for technology-based investment projects with long gestation periods.

The banking system exposed itself to risk both in terms of the sectors it favored for loans and in terms of the collateral it accepted. In normal circumstances it would be acceptable to take property and stocks as collateral. With the build-up of the property bubble and the stock market boom, banks were opening the economy to financial fragility. This was fuelled by the extensive credit that the bank was granting to the private sector. Bank credit to the private sector rose rapidly from 1993 to mid-1997. The rate of growth of bank credit rose from roughly 85 per cent in 1993 to about 150 per cent in 1995. In mid-1997, the figure reached about 160 per cent.

Over the past two decades, many countries around the world have experienced substantial growth in their economies, with even faster growth in international transactions, especially in the form of trade (exports and imports) and foreign direct investment (FDI). The share of net FDI in world GDP has grown five-fold through the eighties and the nineties, making the causes and consequences of FDI and economic growth a subject of ever-growing interest. International free trade has often been referred to as the "engine of growth" that propelled the development of today's economically advanced nations during the nineteenth and early twentieth century's. Rapidly expanding trade especially or specifically the export sector provided an additional stimulus to growing local demands that led to establishment of large scale industries. In Libya, the growth of exports is around ten percent per annum, that means improving economic growth and recovering some fund if the imports less than exports. Exports have tended to grow fastest in countries with more liberal trade regime, and these countries have experienced the fastest growth of GDP.

TABLE 1 Resource Flows and Commodity Trade: 2000-2012 Average

\begin{tabular}{|c|c|c|c|c|}
\hline Country / Group & $\begin{array}{r}\text { FDI } \\
(\% \text { of GDP) }\end{array}$ & $\begin{array}{r}\text { FPI } \\
(\% \text { of GDP })\end{array}$ & $\begin{array}{r}\text { Aid } \\
\text { (\% of GDP) }\end{array}$ & $\begin{array}{r}\text { Trade } \\
\text { (\% of GDP) }\end{array}$ \\
\hline Tunisia & 0.555 & 0.221 & 7.100 & 28.366 \\
\hline Algeria & 0.885 & 0.380 & 0.669 & 20.081 \\
\hline Sudan. & 0.222 & 0.998 & 0.026 & 68.461 \\
\hline Libya & 4.316 & 1.378 & 0.387 & 152.059 \\
\hline Morroco & 0.999 & 0.362 & 2.490 & 35.495 \\
\hline Western Sahara & 1.230 & 0.928 & 1.623 & 69.850 \\
\hline Egypt & 10.038 & n.a. & 0.077 & 329.231 \\
\hline
\end{tabular}

\section{Disscusion}

The report has identified challenges and benefits of FDI in previous chapters, here in this chapter we discussed the enabling policies aimed at benefiting from FDI and scaling through the difficulties also discussed and the policies have two facets, namely policies to attract inward investment, and policies aimed at reaping the maximum benefits from foreign corporate presence.

\section{A. Solution for creating enabling Environment}

Attracting FDI generally relies on the broader enabling environment for investment in the host country (and, depending on national and local circumstances, specific incentives and other inducements to invest) Authorities may, by pursuing an appropriate mix of policies, influence any of these - apart from factors such as natural resource endowment and size of domestic market 1 - thereby boosting their country's attractiveness to foreign investors. The relevant policy levers are summarized in the Overview; they include efforts to improve: macroeconomic stability; physical, financial and technological infrastructure; openness to international trade; non-discrimination; and transparency of the political and regulatory environment. In addition to making the host country more attractive to potential investors, most of these policies will also be instrumental in maximizing the benefits of foreign corporate presence through their impact on the overall quality of the domestic business environment. The present chapter focuses on the importance of transparency, which is commonly identified - in its own right and in connection with efforts to combat corruption - as the single most important factor in attracting investment. The policy options for reaping the benefits of foreign corporate presence also include generic policies to improve domestic infrastructure, technology and skills; specific policies for raising efficiency and promoting competition in the domestic business sector; and measures targeted at the activities of foreignowned enterprises. The latter category includes, in particular, the imposition of performance requirements on foreign direct investors. The second section of this chapter reviews the evidence of the effectiveness of such 
measures, and raises the issue of whether their imposition may create a potentially damaging trade-off between authorities' efforts to attract FDI and their efforts to benefit from it.

\section{B. The importance of international co-operation as solution to FDI Set Back}

International co-operation, whether under the auspices of international organizations or bilaterally, may assist and reinforce the FDI-related efforts of host countries, home countries and multinational enterprises (a point touched upon in the previous section). The added value of co-operation in the context of home countries, or developed countries more broadly, lies in the fact that the fields for policy action suggested above cannot easily be pursued by countries acting alone. Embarking on the vast array of policy measures proposed above for host countries is beyond the capabilities of many poorer nations. This creates a scope for other countries and organizations to help via measures aimed at technical assistance and capacity building.

Against the background of the Libya and Monterrey Declarations, which identify capacity building as a priority area for international co-operation, international organisations and relevant national agencies should carefully assess the need for activities in the field of international investment - particularly FDI. Increased capacitybuilding measures would focus on assisting developing countries to develop stronger competences in the following fields: general supply-side challenges; formulation and implementation of broad-based policies toward FDI; and the specific architecture for negotiating and implementing international treaties and agreements related to foreign investment.

\section{Transparency}

While there is no commonly agreed definition of transparency, most people would agree that a transparent business climate necessarily implies that economic agents must possess essential information about the environment in which they operate and that search costs and information asymmetries not place an undue burden on them. This, in turn, implies that in the FDI context there are two main sources of (lack of) transparency, namely the actions of host-country authorities, and the degree of opacity that prevails more generally in the host country's business sector.

\section{The importance of transparency}

The tentative definition of transparency proposed above suggests channels through which a lack of transparency may deter FDI and, by hampering the proper functioning of the host country's business sector, reduce the benefits of foreign corporate presence. First, it heightens the risk of operating in the host-country business environment, which either translates into higher risk premiums (in the case of the pricing of corporate assets, or discounts) or imposes additional information costs on enterprises. Second, and particularly important from the viewpoint of a new entrant, it raises the risk of information asymmetries that would in most cases benefit the market incumbents. Transparency by itself will not create a motive for investing where market conditions do not justify it, but a lack of transparency will almost certainly discourage foreign investors. For example, frequent public complaints by investors of red tape, bureaucracy and arbitrary decisions all relate to a lack of transparency. If the anticipated returns are high enough, then the investor may be willing to bear the risk uncertainty, but in many developing countries this is not the case. Also, a lack of transparency may lead to adverse selection among foreign investors, if those most likely to invest into a non-transparent environment are companies that are themselves privy to privileged information, or who bank on their ability to influence the host-country public and corporate governance.

\section{E. Transparency of Libya in business environment.}

As noted above, the importance of good governance founded on transparency in order to attract and benefit from foreign investment has its logical counterpart in the private sector in terms of a transparent system of corporate governance. Just as the government wishes to benefit from foreign capital and technology, so too might a local firm benefit from association with a foreign investor. Similarly, just as a lack of transparency in government policies and their implementation raise the risks of investment for a foreign firm, so too does a lack of corporate transparency and A lack of transparency [in standards] may make it difficult or impossible for potential investors to accurately identify the sources of influence and control on the behavior of enterprises. In many cases, investors will want to have some information on the ownership and control of companies that are important competitors, suppliers and customers in the market in question. Transparency of government action The transparency of public governance arguably has a static, an inter temporal and a dynamic aspect. As for the former, the need to establish formal and rigorously enforced legal and regulatory frameworks as a prerequisite for transparency is commonly accepted, as is the notion that transparency needs to pervade every aspect of the administrative process governing FDI (e.g. approvals, regulation of established firms, dispute settlement and taxation). The inter temporal aspect, which has been termed "ex-ante transparency", relates to the degree of clarity that investors can obtain regarding future legal and regulatory changes. Indeed, transparency does not mean that policies cannot be changed, but it does imply that the corporate sector should be given access to as 
much information and prior consultation as the host country's domestic political process should legitimately permit. A separate issue relates to the principle of non-discrimination; since locally owned enterprises often have better knowledge of the intentions of national policy makers, it is a particular challenge for host country authorities to ensure that all parties have equal access to information. As regards the dynamic aspect, transparency may act as a means by which regulations are improved. It imposes a discipline on governments and hence is an integral part of good governance and regulatory reform. The introduction of greater transparency provides a channel through which the effectiveness of policies can be judged. It allows for a review by interested parties and helps to point out redundant, inefficient or inconsistent regulations. By helping to achieve more efficient regulation, transparency ensures that the regulatory framework better fulfills the policy objectives set by government.

\section{F. Creating the broader enabling environment}

The broader enabling environment for FDI is generally identical with best practices for creating a dynamic and competitive domestic business environment. The principles of transparency (both as regards host country regulatory action and business sector practices) and non-discrimination are instrumental in attracting foreign enterprises and in benefiting from their presence in the domestic economy. FDI is unlikely unless investors have a reasonable understanding of the environment in which they will be operating. Moreover, a lack of transparency may lead to illicit and other unethical practices, which generally weaken the host country's business environment.

(Box 2). In this context, host-country authorities should undertake the following measures Strengthen their efforts to consolidate the rule of law and good governance, including by stepping up efforts against corruption and enhancing policy and regulatory frameworks (e.g. as regards competition, financial reporting and intellectual property protection) to foster a dynamic and well-functioning business sector. Such policies will benefit the climate for FDI through their effect on transparency. By bringing a larger share of the informal economy into the open, they will also have important secondary effects on countries' ability to attract investment.

\section{G. Upgrading of the relevant infrastructure}

To reap the maximum benefits from corporate presence in a national economy, domestic competences, technologies and infrastructure need to be sufficiently well developed to allow nationals to take full advantage of the spillovers that foreign-owned enterprises generate. Host country authorities should therefore - with due regard to the balance between costs and expected benefits, and the state of development of the domestic economy - undertake measures to the following effect and Put in place, and raise the quality of, relevant physical and technological infrastructure. The presence of such infrastructure is instrumental in attracting MNEs, in allowing national enterprises to integrate the technological spinoffs from foreign-owned enterprises in their production processes, and in facilitating their diffusion through the host economy. Allowing foreign investment in infrastructure sectors and leveraging such investment by means of ODA may assist in these efforts. Given the importance of basic, widespread education for development, raise the basic level of education of national workforces. The provision of specialised skills beyond basic education should build on existing competences in the host economy, rather than target the short-term or specific needs of individual foreign owned enterprises. A healthy workforce population is also needed, which requires basic public health infrastructure.

\section{H. Political stability and FDI growth in Libya}

Stable political and policy environments are also attractive investment determinants. Host countries can turn domestic economies into more attractive investment environments by reducing political risk and promoting stable and liberal policy to attract more foreign investment, although these are long-term changes. As the literature on the determinants of FDI informs, political and institutional risk is one of the major concerns for foreign investors, especially in developing nations. Such as annulment or change of the terms of foreign investment, continue to pose a great challenge to foreign investors in developing markets. In addition, recent high profile revolution in the Libya not only stress the prevalence of political violence and the importance of political risk as a challenge to foreign investors, but also highlight that even oil producing country like Libya are not immune to political risk and violence.

A host economy with high political risk tends to discourage FDI flows into its market, since political volatility hurts the profitability of foreign investment. Three major types of political risk discourage foreign investment since they damage its profitability and survival: first, nationalization or expropriation of foreign assets, which tends to be rare, and breach of contract, which occurs more often, threaten foreign investment; second, policy instability and arbitrary regulation in FDI-related policies create uncertain investment environments and hurt the profitability of foreign investments; and, third, war and political violence, including terrorist activities, can damage foreign assets immediately and discourage the productivity of a host economy in the long run. 


\section{Summary}

The report has studied and analysis effort on economic growth through FDI in Libya from the analysis it is now clear that the three major factors the may be particularly pertinent in Libyan FDI are macroeconomic instability; loss of assets due to non-enforceability of contracts; and physical destruction caused by armed conflicts in recent revolution. The second of these may be particularly discouraging to investors domiciled abroad, since they are generally excluded from the informal networks of agreements and enforcement that develop in the absence of a transparent judicial system. Several other factors holding back FDI have been proposed in In this report, notably the perceived sustainability of national economic policies, poor quality of public services and closed trade regimes. Even where the obstacles to FDI do not seem insurmountable, investors may have powerful incentives to adopt a wait and-see attitude.

FDI (and especially greenfield investment) contains an important irreversible element, so where investors' risk perception is heightened the inducement would have to be massive to make them undertake FDI as opposed to deferring their decision. This problem is compounded where a deficit of democracy, or of other kinds of political legitimacy, makes the system of government prone to sudden changes. Finally, a lack of effective regional trade integration efforts has been singled out as a factor. Due to this, national markets remained small and grew at a modest pace (and, in some cases, they even contracted). A few countries have, however, been able to attract FDI, apparently by virtue of the quality of their domestic business climates. Countries such as Mozambique, Namibia, Senegal and Mali in the late 1990s became perceived as having a relatively benign investment environment where Libya need to immulate.

The Libyan authorities can facilitate economic growth by the exploitation of economics of scale, reduce the obligatory constraint to allow increases in the import of capital and intermediate goods enhancing efficiency through increased competition, and promoting the diffusion of knowledge through learning by doing the results of this report support the argument that trade openness will continue to be viewed as a key factors of economic growth.

\section{Reference}

[1] 1). Abobaker Salem (2011) “An Investigation on Foreign Direct Investment and Technology Transfer Comparative Study of Libya and Egyp "t , International Review of Business Research Papers Vol. 7. No. 2. March 2011. Pp. 212-229.

[2] 2). Andrew W. Lo (2012) “The Global Financial Crisis of 2008: The Role of Greed, Fear, and Oligarchs” Rev. March 16, 2012.

[3] 3). Barlow D. (2006) "Growth in Transition Economies: A Trade Policy Perspective” Economics of Transition. Vol 14 (3) 2006 pp 505-514.

[4] 4). Chakraborty, C. \& Basu, P. 2002. "Foreign Direct Investment and Growth in India: a cointegration approach", Applied Economics, 34:1061-1073.

[5] 5). Chowdhury ,A. Mavrotas,G.(2005), “FDI and Growth: A Causal Relationship,” WIDER.Research Paper.

[6] 6). Coker Margaret and Rappaport, Liz (2011), “Libya's Goldman Dalliance Ends in Losses,Acrimony” The Wall Street Journal, Retrieved 9 September 2011.

[7] 7). Dhakal, I.P. and B.B. Thapa, 2002. “Economic impact of clinical mastitis in the buffaloes in Nepal”. Buffalo J., 2: $225-234$.

[8] 8). Dharmendra Dhakal, Saif Rahman \& Kamal P. Upadhyaya, 2007, "Foreign Direct Investment and Economic Growth In Asia”, Indian Journal of Economics and Business

[9] 9). Vadlamannati, K., \& Tamazian, A. (2009). "Growth Effects of FDI in Eighty Developing Economies: The Role of Policy Reforms and Institutional Constraints”. Journal of Economic Policy Reform, 12(4), 299-322 